Research Article

\title{
Hydration of Reactive MgO as Partial Cement Replacement and Its Influence on the Macroperformance of Cementitious Mortars
}

\author{
T. Gonçalves, ${ }^{1}$ R. V. Silva $\mathbb{D}^{2},{ }^{2}$. de Brito, ${ }^{2}$ J. M. Fernández, ${ }^{3}$ and A. R. Esquinas ${ }^{4}$ \\ ${ }^{1}$ Instituto Superior Técnico, Universidade de Lisboa, Av. Rovisco Pais, 1049-001 Lisboa, Portugal \\ ${ }^{2}$ CERIS, Instituto Superior Técnico, Universidade de Lisboa, Av. Rovisco Pais, 1049-001 Lisboa, Portugal \\ ${ }^{3}$ Department of Inorganic Chemistry and Chemical Engineering, Universidad de Córdoba, Campus de Rabanales, \\ Edificio Marie Curie, Planta Baja y $1^{a}$ Planta, 14071 Córdoba, Spain \\ ${ }^{4}$ Department of Inorganic Chemistry and Chemical Engineering, Engineering School Science of Belmez, 14240 Córdoba, Spain
}

Correspondence should be addressed to R. V. Silva; rui.v.silva@tecnico.ulisboa.pt

Received 5 November 2018; Revised 17 January 2019; Accepted 4 February 2019; Published 26 February 2019

Academic Editor: Jose M. Monzo

Copyright (c) 2019 T. Gonçalves et al. This is an open access article distributed under the Creative Commons Attribution License, which permits unrestricted use, distribution, and reproduction in any medium, provided the original work is properly cited.

\begin{abstract}
A recent quest for more sustainable cement-based construction materials has triggered the pursuit of technically viable alternatives of cement, making reactive magnesium oxide $(\mathrm{MgO})$ one of the least known top contenders to reduce this sector's environmental impact since it participates in the cement's hydration reactions and presents enhanced carbon capture ability during its life cycle. In this study, two different commercially available reactive $\mathrm{MgO}$ samples were evaluated as partial cement replacements (at $10 \%, 15 \%$, and $20 \%$, by weight) in the production of mortars. Thermogravimetric analysis (TGA), energydispersive X-ray (EDX) analysis, differential thermal analysis (DTA), and powder X-ray diffraction (XRD) analysis of cement, $\mathrm{MgO}$ samples, and resulting mortars were carried out. All specimens were evaluated in terms of their mechanical and durabilityrelated performance (i.e., flexural and compressive strength, carbonation, water absorption by capillary action, and shrinkage). The main results suggest that, in spite of the decreased, albeit acceptable, performance with increasing incorporation of $\mathrm{MgO}$ as partial cement replacement, a significant decrease was observed in the shrinkage strain of cementitious materials.
\end{abstract}

\section{Introduction}

Cement industry is one of the most polluting industries in the world, contributing around $5 \%$ to $7 \%$ of the total global $\mathrm{CO}_{2}$ emission [1], thereby making it of fundamental importance to seek new solutions that can further decrease its environmental impact. Some of the solutions involve improving the calcination process energy efficiency, using alternative fuels or raw materials, and exploring the role of cement systems in carbon capture and storage technologies [2]. Among the aforementioned, the one considered the most effective from an environmental impact reduction point of view is direct replacement of cement (i.e., supplementary cementitious materials) with constituents that partake in the hydration and strength development processes, especially if sourced from industrial wastes (e.g., fly ash, ground granulated blastfurnace slag, palm oil fuel ash, and electric-arc furnace dust) [3-6]. This makes the use of reactive magnesium oxide $(\mathrm{MgO})$ a unique opportunity to reduce the resulting composite's carbon footprint, as well as to improve some of its features [7].

The use of MgO-based constituents in the clinkerization process has been restricted to no more than $5 \%$ of $\mathrm{MgO}$ [8], as the high temperatures involved in this process would yield the production of dead-burned $\mathrm{MgO}$ with a very slow hydration rate [9]. Consequently, the late expansion of $\mathrm{MgO}$ in a hardened and stable cementitious microstructure would jeopardize its soundness. However, this is not the case for $\mathrm{MgO}$ subjected to lower calcination temperatures (i.e., light burned $\mathrm{MgO}$ calcined at $700-1000^{\circ} \mathrm{C}$ ). Not only does it 
typically present a great reactivity and early age expansion [10-12], but its overall $\mathrm{CO}_{2}$ emissions were reported to be up to $73 \%$ lower than those of cement [13], considering the higher carbon capture capacity of $\mathrm{MgO}$-based cements throughout their life cycle [7, 14, 15].

Hydration reaction of $\mathrm{MgO}$, which leads to the formation of $\mathrm{Mg}(\mathrm{OH})_{2}$, is as follows [16]:

$$
\mathrm{MgO}+\mathrm{H}_{2} \mathrm{O} \longrightarrow \mathrm{Mg}^{2+}+2 \mathrm{OH}^{-} \longrightarrow \mathrm{Mg}(\mathrm{OH})_{2}
$$

Since the volume of hydration products is higher than that of the reagents, the hydration of $\mathrm{MgO}$ leads to an expansion, which, if properly controlled, may be used to compensate the shrinkage typically observed in cementitious composites [10,17-21] and possibly their deformation due to creep as well. The compatible chemical nature of $\mathrm{MgO}$ with that of cement may produce beneficial expansive components capable of reducing the number of microcracks and contribute to strength gain under certain circumstances [22]. Similar to that observed in the hydration of cement, after the formation of $\mathrm{Mg}(\mathrm{OH})_{2}$, ensuing pozzolanic reactions can lead to the formation of magnesium silicate hydrates (i.e., $\mathrm{MgO}-\mathrm{SiO}_{2}-\mathrm{H}_{2} \mathrm{O}$ or $\mathrm{M}-\mathrm{S}-\mathrm{H}$ ) [23] capable of presenting considerable strength gain [24], if in the presence of amorphous silica-bearing mineral additions, such as fly ash $[25,26]$ or silica fume $[27,28]$. Another practical feature of using reactive $\mathrm{MgO}$-based cementitious composites is their ability to capture a considerable amount of $\mathrm{CO}_{2}$ thereby further decreasing the material's environmental impact throughout its life cycle. Furthermore, the carbonation of brucite may result in phases (i.e., magnesium carbonate hydrates such as nesquehonite, hydromagnesite, dypingite, and artinite) capable of significantly increasing the strength of the matrix $[29,30]$.

There have been quite a few studies on the microstructure of cementitious composites containing reactive $\mathrm{MgO}$, by means of X-ray diffraction (XRD) and thermogravimetric analyses $[11,23,31-36]$, specifically on the formation of $\mathrm{Mg}(\mathrm{OH})_{2}$ and $\mathrm{M}-\mathrm{S}-\mathrm{H}$ phases [16, 37]. Various reports based on SEM analyses have suggested that the hydration products of $\mathrm{MgO}$ exhibit a tendency to migrate towards the interfacial transition zone (ITZ) area thereby reducing the porosity of the resulting material [38-41].

In the light of the recent positive findings regarding this component and its practical impact in the construction industry, this paper reports the interaction of the hydration products of commercially available $\mathrm{MgO}$, from two different sources, with those of cement, from a cementitious microstructure viewpoint and its implications on the composite's macroperformance. This study is the first of upcoming statefunded research projects, involving various companies within the construction sector. Contrasting with the mix design of other research studies, which typically involve lower replacement levels of cement with $\mathrm{MgO}$, relatively high contents of $10 \%, 15 \%$, and $20 \%$, by weight, of $\mathrm{MgO}$ samples were used as cement replacement thus constituting one of the novelties of this paper. These relatively higher contents were chosen with the purpose of further reducing the environmental impacts of concrete, given the considerable carbon capture of
MgO-containing cementitious systems, and also its costs since the manufacture of cement is an energy-intensive process unlike that of light burned $\mathrm{MgO}$. Thermogravimetric analysis (TGA), energy-dispersive X-ray (EDX) analysis, differential thermal analysis (DTA), and powder XRD analysis were carried out on cement, the two MgO samples, and selected mortars. The specimens' mechanical- and durability-related performances were evaluated by means of their flexural and compressive strength, carbonation, water absorption by capillary action, and shrinkage.

\section{Materials and Methods}

2.1. Cement and $\mathrm{MgO}$. The cement used was CEM I 42.5R, and its chemical composition is presented in Table 1. The cement presents initial and final setting times of $161 \mathrm{~min}$ and $232 \mathrm{~min}$, respectively. The water used in the production of all specimens was potable tap water.

Two types of $\mathrm{MgO}$ were used: $\mathrm{MgO} \mathrm{A}$ was supplied by Styromag, an Austrian company, and MgO G from Grecian Magnesite S.A., a Greek company. Both are light burned $\mathrm{MgO}$ due to their relatively low calcination temperature of about $800^{\circ} \mathrm{C}$ [11]. Both $\mathrm{MgO}$ samples' chemical compositions are presented in Table 1. The morphology of both $\mathrm{MgO}$ samples can be observed by means of the scanning electron microscopy (SEM) micrographs presented in Figure 1.

The particle-size distributions of cement and both $\mathrm{MgO}$ samples are presented in Figure 2(a). MgO A and cement present similar distributions, as most of their particles have a diameter between $10 \mu \mathrm{m}$ and $60 \mu \mathrm{m}$. MgO G, which is similar to $\mathrm{MgO} \mathrm{A}$, contains slightly smaller particles (mostly between $10 \mu \mathrm{m}$ and $30 \mu \mathrm{m}$ ) and presents a less extensive particle-size distribution when compared to the other two. About $52.1 \%$ and $65.3 \%$ of the particles of $\mathrm{MgO} \mathrm{A}$ and $\mathrm{MgO}$ $\mathrm{G}$, respectively, were found in the range of $3 \mu \mathrm{m}-32 \mu \mathrm{m}$. Above $32 \mu \mathrm{m}$ (20.2\% of $\mathrm{MgO} \mathrm{A}$ and $3.5 \%$ of $\mathrm{MgO} \mathrm{G})$, the particles may be too large to hydrate rapidly, and below $3 \mu \mathrm{m}$ (27.7\% of $\mathrm{MgO} \mathrm{A}$ and $31.1 \%$ of $\mathrm{MgO} \mathrm{G}$ ), they may have a smaller contribution to the mechanical strength and simultaneously demand more water [42-44]. The bulk densities of $\mathrm{MgO} \mathrm{A}, \mathrm{MgO} \mathrm{B}$, and cement were 653, 618, and $1040 \mathrm{~kg} / \mathrm{m}^{3}$, respectively.

The BET specific surface areas of $\mathrm{MgO} \mathrm{A}$ and $\mathrm{MgO} \mathrm{G}$ were $20.12 \mathrm{~m}^{2} / \mathrm{g}$ and $18.01 \mathrm{~m}^{2} / \mathrm{g}$, respectively. The pore size distributions, obtained from the adsorption-desorption isotherms of $\mathrm{N}_{2}$, are shown Figure 2(b). Both additions show a range of pore diameter of 4-200 $\mathrm{nm}$, according to the $\mathrm{BJH}$ method. Although the distribution of the pore volume is comparable in both materials, for $\mathrm{MgO} \mathrm{A}$, the highest quantity of the pore volume is centred at a slightly lower pore diameter than MgO G (23 nm vs. $33 \mathrm{~nm}$, respectively).

The results of the XRD analysis are presented in Figure 3. The pattern of $\mathrm{MgO} \mathrm{A}$ shows that the main phase was periclase $(\mathrm{MgO})$ (International Centre for Diffraction DataICDD \#45-0946), suggesting its crystallinity due to the narrow peak. For $\mathrm{MgO} \mathrm{A}$, peaks corresponding to the presence of calcite $\left(\mathrm{CaCO}_{3}\right)$ (ICDD \#05-0586), dolomite $\left(\mathrm{CaMg}\left(\mathrm{CO}_{3}\right)_{2}\right)$ (ICDD \#36-0426), and talc (ICDD \#13-0558) are also visible. The presence of the first two could also be 
TABLe 1: Chemical composition of cement and $\mathrm{MgO}$ (\% by mass).

\begin{tabular}{|c|c|c|c|c|c|c|c|c|c|c|c|c|}
\hline Component & $\mathrm{SiO}_{2}$ & $\mathrm{Al}_{2} \mathrm{O}_{3}$ & $\mathrm{Fe}_{2} \mathrm{O}_{3}$ & $\mathrm{CaO}$ & $\mathrm{MgO}$ & $\mathrm{SO}_{3}$ & $\mathrm{CuO}$ & $\mathrm{ZnO}$ & $\mathrm{C}_{3} \mathrm{~S}$ & $\mathrm{C}_{2} \mathrm{~S}$ & $\mathrm{C}_{3} \mathrm{~A}$ & $\mathrm{C}_{4} \mathrm{AF}$ \\
\hline CEM I 42.5R & 19.5 & 5.0 & 3.3 & 63.5 & 1.3 & 3.3 & - & - & 57.7 & 16.5 & 4.3 & 11.2 \\
\hline $\mathrm{MgO} \mathrm{A}$ & 4.6 & - & 7.4 & 5.5 & 78.6 & - & 2.8 & 1.1 & - & - & - & - \\
\hline $\mathrm{MgO} \mathrm{G}$ & - & - & - & 4.4 & 89.5 & - & 3.4 & 2.6 & - & - & - & - \\
\hline
\end{tabular}

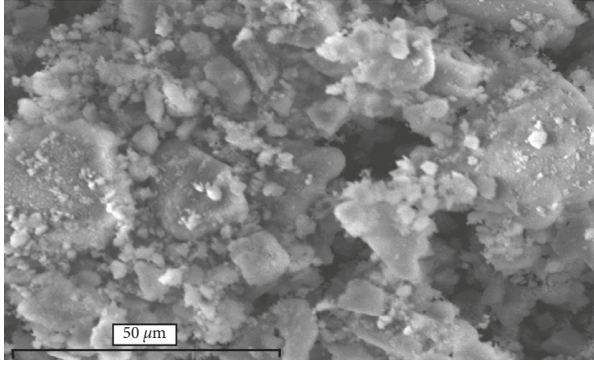

(a)

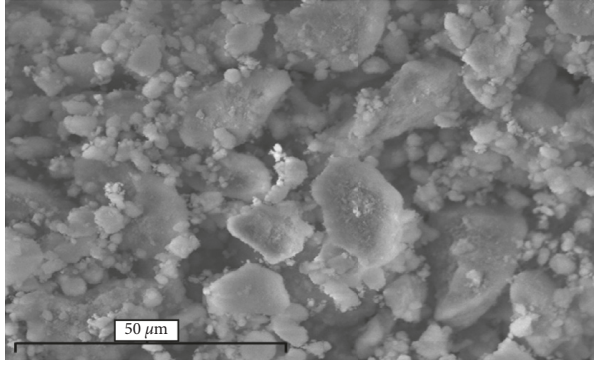

(b)

Figure 1: SEM micrographs of (a) MgO A and (b) MgO G.

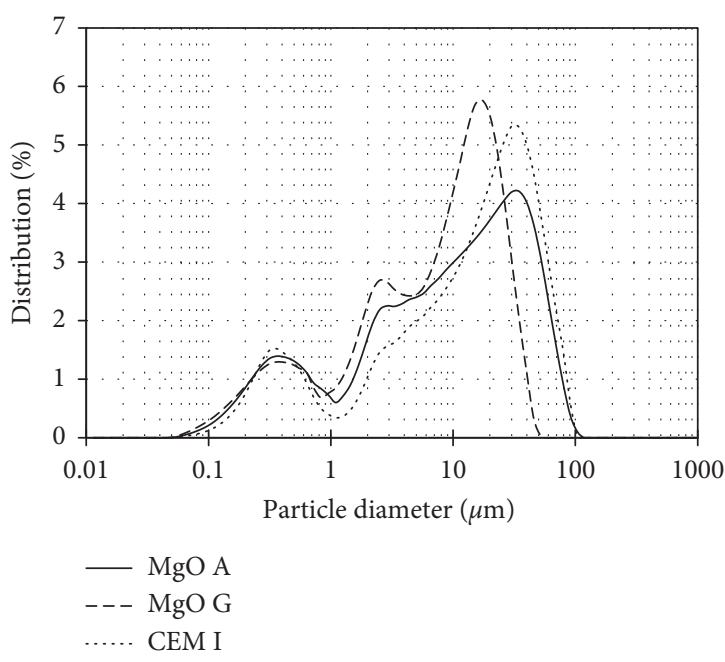

(a)

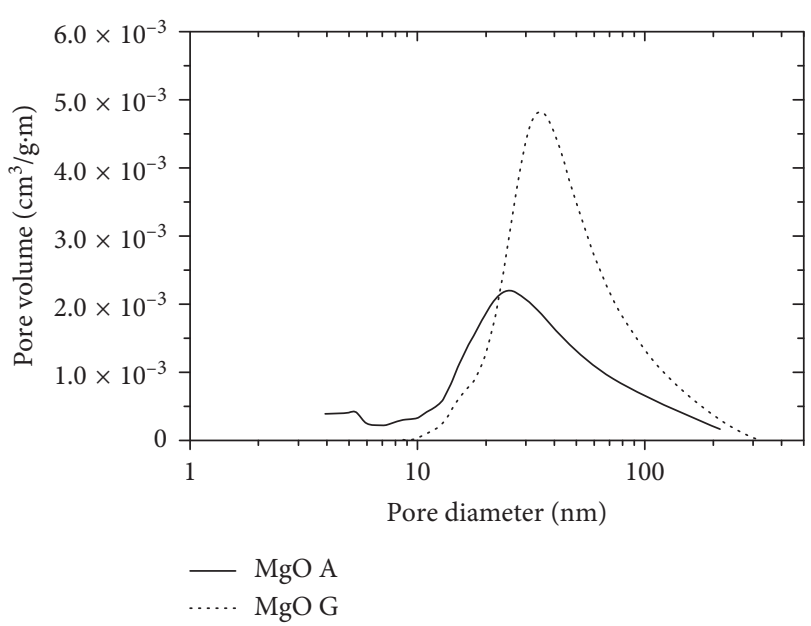

(b)

Figure 2: Particle-size distributions by using laser diffraction (a) and pore volume (b) of MgO A, MgO G, and cement.

observed in the TGA in Figure 4(a). Unlike the XRD pattern of $\mathrm{MgO} \mathrm{A}$, the one of $\mathrm{MgO} \mathrm{G}$ shows just a periclase phase. The absence of other smaller phases indicates a lower degree of impurity when compared to $\mathrm{MgO} \mathrm{A}$.

Figure 4 presents the results of TGA and DTA of $\mathrm{MgO} A$ and $\mathrm{MgO}$ G. The initial weight loss up to $150^{\circ} \mathrm{C}$, slightly higher in $\mathrm{MgO} \mathrm{G}$ when compared to that in $\mathrm{MgO} \mathrm{A}$, is possibly due to the $\mathrm{OH}$ group residual in the surface of the material or to the presence of the hydromagnesite compound. At temperatures between $300^{\circ} \mathrm{C}$ and $400^{\circ} \mathrm{C}$, a weight loss was observed in $\mathrm{MgO} \mathrm{G}$ (4.67\%), attributable to the dehydroxylation of $\mathrm{Mg}(\mathrm{OH})_{2}$. This suggests greater partial hydration of $\mathrm{MgO} \mathrm{G}$ in comparison with $\mathrm{MgO} \mathrm{A}$. The increase in weight loss and decrease in heat flow up to around $750^{\circ} \mathrm{C}$ may have been due to the decarbonation of calcite $\left(\mathrm{CaCO}_{3}\right)$ and dolomite $\left(\mathrm{CaMg}\left(\mathrm{CO}_{3}\right)_{2}\right)$ as suggested by the XRD patterns of $\mathrm{MgO}$ A.
2.2. Characterization of Aggregates. The sand's particle-size distribution was made in accordance with EN 1015-1 [45]. The bulk density was evaluated according to EN 1097-3 [46], whereas water absorption and apparent density as per EN 1097-6 [47]. The fine particles content classification was determined in accordance to EN 13139 [48]. The physical properties and particle-size distributions of both fine and coarse sand $(0 / 2$ and $0 / 4 \mathrm{~mm}$, respectively) are presented in Table 2.

An XRD analysis was also carried out on the sand used in this study (Figure 5). Both fine and coarse sand showed that the main phase was quartz (crystalline $\mathrm{SiO}_{2}$ ) (ICDD \#33-1161) and were thus expected to have marginal reactivity with the cement's products of hydration and $\mathrm{Mg}(\mathrm{OH})_{2}$. The presence of orthoclase (ICDD \#31-0966), albite (ICDD \#41-1480), and microcline (ICDD \#19-0926) was observed. 


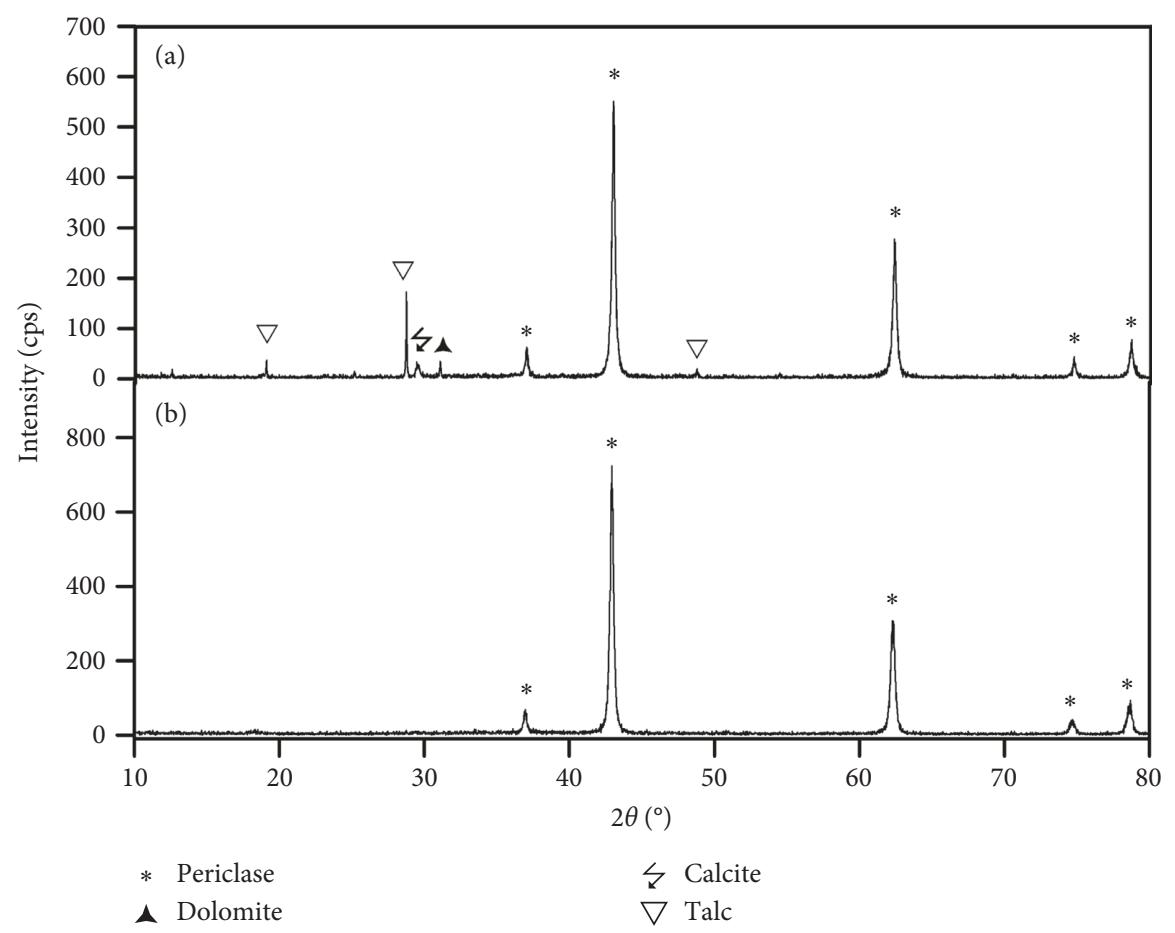

FIgURE 3: XRD patterns for $\mathrm{MgO} \mathrm{A}$ (a) and $\mathrm{MgO} \mathrm{G}(\mathrm{b})$.

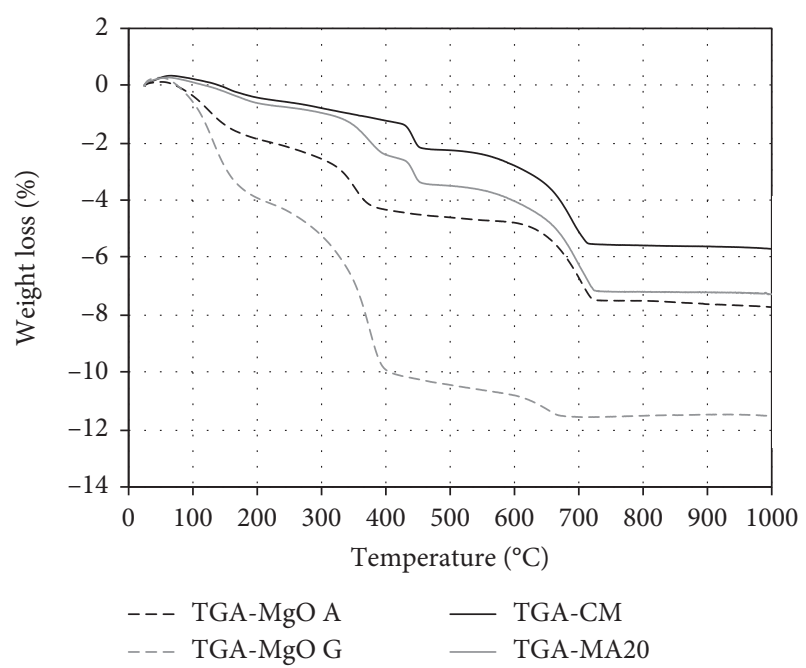

(a)

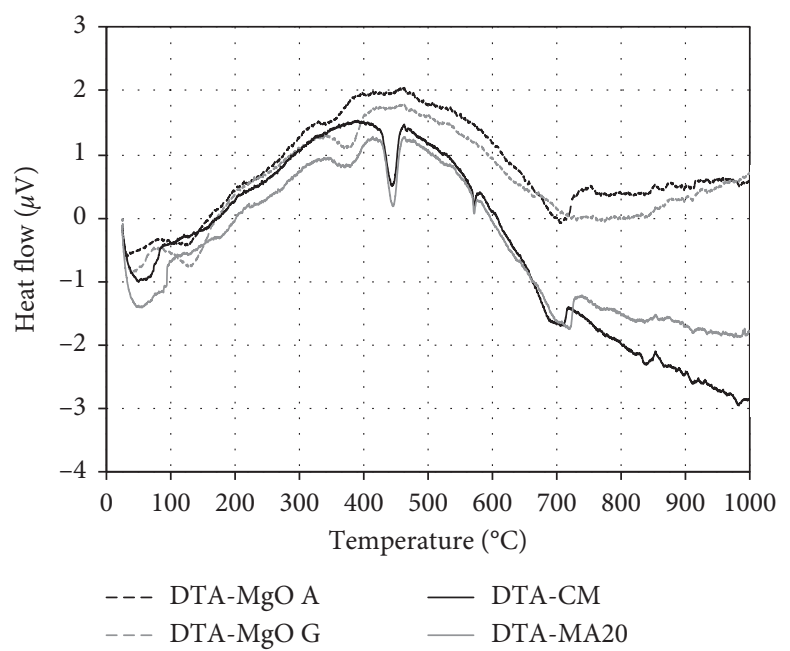

(b)

Figure 4: TGA (a) and DTA (b) of the two MgO samples and of the control mortar (CM) and mortar with 20\% MgO A (MA20).

2.3. Mix Design. The mortar's composition was based on the method proposed by Nepomuceno et al. [49], and the contents are presented in Table 3. The method adopted for the mix design allows the production of mortars exhibiting characteristics and performance equivalent to those of a concrete counterpart and not mortars typically used in rendering and masonry. All mortars were produced with a volumetric ratio of $1 / 3$ (binder/aggregate). The mixes' spread was fixed at $200 \pm 15 \mathrm{~mm}$, which was achieved by varying the water/binder $(w / b)$ ratio, starting from 0.50 for the control mixes (CMs). The cement was partially replaced by each type of $\mathrm{MgO}$ with the ratios of $10 \%, 15 \%$, and $20 \%$, by weight. Mortars incorporating $\mathrm{MgO} \mathrm{A}$ and $\mathrm{MgO} \mathrm{G}$, henceforth, are MA and MG, respectively.

2.4. Test Methods. The unbound constituents and the resulting hardened specimens were analyzed by means of XRD patterns using a Bruker D8 Discover A25 instrument with $\mathrm{Cu}-\mathrm{K} \alpha$ radiation. All diffraction patterns were obtained by scanning using a goniometer from $10^{\circ}$ to $80^{\circ}(2 \theta)$ at a rate of $0.05^{\circ} \cdot \mathrm{s}^{-1}$. TGA was performed using a Setaram SETSYS 
TABLE 2: Characteristics of fine and coarse sand.

\begin{tabular}{lcc}
\hline Properties & Fine sand & Coarse sand \\
\hline Nominal size $(d / D)$ & $0 / 2$ & $0 / 4$ \\
Apparent density $\left(\mathrm{g} / \mathrm{cm}^{3}\right)$ & 2.62 & 2.63 \\
Oven-dry density $\left(\mathrm{g} / \mathrm{cm}^{3}\right)$ & 2.60 & 2.61 \\
Saturated and surface-dry density $\left(\mathrm{g} / \mathrm{cm}^{3}\right)$ & 2.61 & 2.62 \\
Water absorption $(\%)$ & 0.23 & 0.25 \\
Fine particles content & Category 1 & $\leq 0.01$ \\
Chloride content $(\%)$ & $\leq 0.01$ & Category 1 \\
Particle-size distribution $(\mathrm{mm})$ & Cumulative retained material for fine and coarse sand (\%) \\
4.0 & & 100 \\
2.0 & & 93.2 \\
1.0 & & 77.4 \\
0.5 & & 50.9 \\
0.25 & & 15.6 \\
0.125 & & 1.4 \\
0.063 & & 0.0 \\
\hline
\end{tabular}

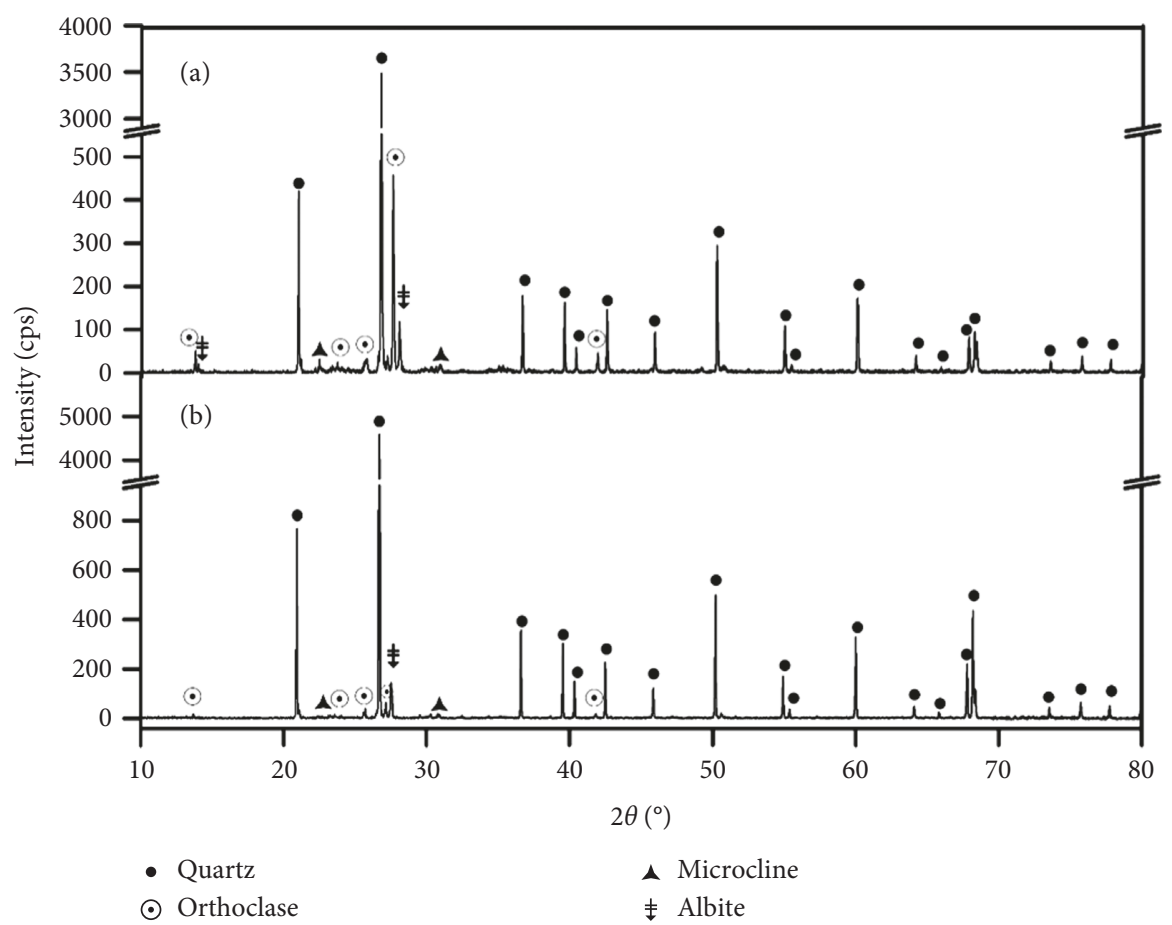

FIGURE 5: XRD patterns for (a) fine sand (FS) and (b) coarse sand (CS).

TABle 3: Composition of mortars.

\begin{tabular}{lcccc}
\hline Mix & Cement $\left(\mathrm{kg} / \mathrm{m}^{3}\right)$ & $\mathrm{MgO}\left(\mathrm{kg} / \mathrm{m}^{3}\right)$ & Water $\left(\mathrm{kg} / \mathrm{m}^{3}\right)$ & Sand $\left(\mathrm{kg} / \mathrm{m}^{3}\right)$ \\
\hline CM & 560.7 & - & 280.3 & 1406.9 \\
MA10 & 504.6 & 56.1 & 280.3 & 1406.9 \\
MA15 & 476.6 & 84.1 & 294.3 & 1406.9 \\
MA20 & 448.5 & 112.1 & 304.3 & 1406.9 \\
MG10 & 504.6 & 56.1 & 280.3 & 1406.9 \\
MG15 & 476.6 & 84.1 & 342.3 & 1406.9 \\
MG20 & 448.5 & 112.1 & 342.3 & 0.50 \\
\hline
\end{tabular}

CM: control mortar; MA: mortars with $\mathrm{MgO}$ A; MG: mortars with $\mathrm{MgO}$ G.

Evolution $16 / 18$ apparatus at a heating rate of $5^{\circ} \mathrm{C} / \mathrm{min}$. The electron microprobe technique was conducted using an electron microscope JEOL JSM-6300 at an acceleration voltage of $20 \mathrm{kV}$ and a working distance of $15 \mathrm{~mm}$. The X-ray detector model is Oxford Instruments ATW2-6699. The particle sizes were measured using a Mastersizer S laser 
diffraction particle size analyzer (Malvern Instruments) with ethanol as dispersant.

Mortars were produced and cast in accordance with EN 1015-2 [50]. Fresh mortars were tested for their consistence [51] and bulk density [52]. Hardened mortars were evaluated in terms of their flexural and compressive strength (3 and 6 specimens, respectively, per mix and age; total of 105 and 210 specimens, respectively) [53], carbonation (3 specimens per mix and age; total of 42 specimens, carbonation chamber with $5 \pm 0.1 \% \mathrm{CO}_{2}, 60 \pm 5 \% \mathrm{RH}$, and at a temperature of $23 \pm 3^{\circ} \mathrm{C}$ ) [54], water absorption by capillary action (3 specimens per mix; total of 21 specimens) [55], and shrinkage (2 specimens per mix; total of 14 specimens) [56].

\section{Results and Discussion}

3.1. Physicochemical Characterization of Hardened Mortars. Figure 4 presents the TGA and DTA of control mortars and those incorporating $20 \% \mathrm{MgO} \mathrm{A}$ as partial cement replacement with a curing age of 28 days. The initial mass loss for temperatures up to $200^{\circ} \mathrm{C}$ can be attributed to the dehydration of $\mathrm{C}-\mathrm{S}-\mathrm{H}$ and $\mathrm{AFt}$ phases. The thermal decomposition of M-S-H usually occurs in the same range of temperatures [24] and thus cannot be clearly observed, but it is likely that this phase did not form due to lack in the presence of amorphous $\mathrm{SiO}_{2}$ capable of reacting with $\mathrm{Mg}(\mathrm{OH})_{2}$ [35]. Two drops are readily noticeable for MA20 between $300^{\circ} \mathrm{C}$ and $500^{\circ} \mathrm{C}$. The first one, between $300^{\circ} \mathrm{C}$ and $400^{\circ} \mathrm{C}$, can be attributed to the dehydroxylation of $\mathrm{Mg}(\mathrm{OH})_{2}$. The second drop, observed in both specimens, between $400^{\circ} \mathrm{C}$ and $500^{\circ} \mathrm{C}$, is due to the dehydroxylation of $\mathrm{Ca}(\mathrm{OH})_{2}$, as a result of the cement's hydration. The final endothermic peak at around $700^{\circ} \mathrm{C}$ may be attributed to the decarbonation of $\mathrm{CaCO}_{3}$ for control mixes and both $\mathrm{CaCO}_{3}$ and $\mathrm{MgCO}_{3}$ for MA20 specimens.

Figure 6 presents the results of the XRD analysis of the $\mathrm{CM}$ and MA20 specimens. It is clear from both patterns that the main mineral phase was quartz (ICDD \#33-1161), being a result of the incorporation of sand. The presence of portlandite $\left(\mathrm{Ca}(\mathrm{OH})_{2}\right)$ (ICDD \#04-0733), from the hydration of cement, was also noted; and, to a lesser extent, calcite (ICDD \#05-0586), albite (ICDD \#41-1480), orthoclase (ICDD \#31-0966), $\mathrm{Ca}_{3} \mathrm{SiO}_{5}$ (ICDD \#42-0551), and microcline (ICDD \#19-0926) were noted. For MA20, quartz (ICDD \#33-1161) was also the main mineral phase. Other phases include portlandite (ICDD \#04-0733), calcite (ICDD \#05-0586), albite (ICDD \#41-1480), orthoclase (ICDD \#310966), $\mathrm{Ca}_{3} \mathrm{SiO}_{5}$ (ICDD \#42-0551), microcline (ICDD \#190926), dolomite (ICDD \#36-0426), periclase (ICDD \#450946), and talc (ICDD \#13-0558); the last three were derived from the incorporation of $\mathrm{MgO} \mathrm{A}$.

3.2. Flexural and Compressive Strength. Figures 7(a) and 7(b) present the flexural and compressive strength, respectively, of all mixes at $3,7,14,28$, and 56 days. A general decrease in strength can be observed with increasing $\mathrm{MgO}$ content, which was also observed by other researchers assessing lower replacement levels [57]. The magnitude of this decrease in strength is more noticeable for MG specimens. This decline is a result of two factors, i.e., the need to increase the $w / b$ ratio and the cement's dilution with increasing $\mathrm{MgO}$ content. In the former, the additional water led to a more porous microstructure for specimens containing 15\% and 20\% $\mathrm{MgO}$. In the latter, the addition of $\mathrm{MgO}$ as cement replacement, in spite of the formation of $\mathrm{Mg}(\mathrm{OH})_{2}$, leads to a decreasing quantity of available $\mathrm{C}_{2} \mathrm{~S}$ and $\mathrm{C}_{3} \mathrm{~S}$ and consequently of C-S-H phases $[35,58,59]$. Nevertheless, if in the presence of an addition with amorphous $\mathrm{SiO}_{2}$, a greater rate of strength development could be observed as a result of pozzolanic reactions with $\mathrm{Mg}(\mathrm{OH})_{2}$ [25]. Although the formation of $\mathrm{Mg}(\mathrm{OH})_{2}$ is vital for strength gain at early curing ages, the ensuing formation of $\mathrm{M}-\mathrm{S}-\mathrm{H}$ will be the main contributing factor of the improvement of cementitious materials incorporating $\mathrm{MgO}$ [23]. Moreover, the existence of alumina from aluminosilicate mineral additions may also offer an advantage concerning the material's mechanical behaviour. It may interact with $\mathrm{Mg}(\mathrm{OH})_{2}$ and form a hydrotalcite-like phase [60] that is capable of enhancing the overall mechanical performance through improved bond with the cementitious matrix [23] and due to the hydrate's ability of decreasing the porosity of the resulting composite [61].

Concerning the strength development of MA and MG, the former presented improved performance when compared to the latter. One of the reasons for this may be due to the fact that $\mathrm{MgO}$ A presented a more extensive particle-size distribution similar to that of cement (Figure 2), which may have improved the packing of the resulting mortar specimens. Furthermore, as a result of the smaller particle size and greater surface area of $\mathrm{MgO}$, more water was required (Table 3) to obtain mixes with comparable workability levels. Naturally, this led to a more porous and less resistant microstructure. Still, in cases wherein an additional amount of water was not required (i.e., MA10 and MG10), specimens containing $\mathrm{MgO}$ A exhibited lower loss in performance. The TGA on both $\mathrm{MgO}$ samples showed that MgO G presented a greater mass loss probably due to the dihydroxylation of $\mathrm{Mg}(\mathrm{OH})_{2}$ (mass losses of $1.76 \%$ and $4.67 \%$ within the $300-400^{\circ} \mathrm{C}$ range for $\mathrm{MgO} \mathrm{A}$ and $\mathrm{MgO} \mathrm{G}$, respectively), which suggests that it was already partially hydrated and did not contribute to the mortars' strength gain as effectively as $\mathrm{MgO}$ A.

3.3. Carbonation. Table 4 presents the carbonation depth of the $\mathrm{MgO}$-containing specimens after being exposed for 28 and 91 days in a $\mathrm{CO}_{2}$ chamber. The results show greater carbonation depths with increasing $\mathrm{MgO}$ content, and there is no significant difference between MA and MG specimens. Even though less porous microstructures incorporating $\mathrm{MgO}$ have been observed elsewhere [25, 62] suggesting reduced carbonation, the opposite trend was observed in the present study, and in others $[62,63]$, they were substantiated by the results in Figure 8 . The higher porosity in mixes containing increasing $\mathrm{MgO}$ content may have led to a greater surface area within the cementitious microstructure available to carbonate in the presence of $\mathrm{CO}_{2}$. Nevertheless, 


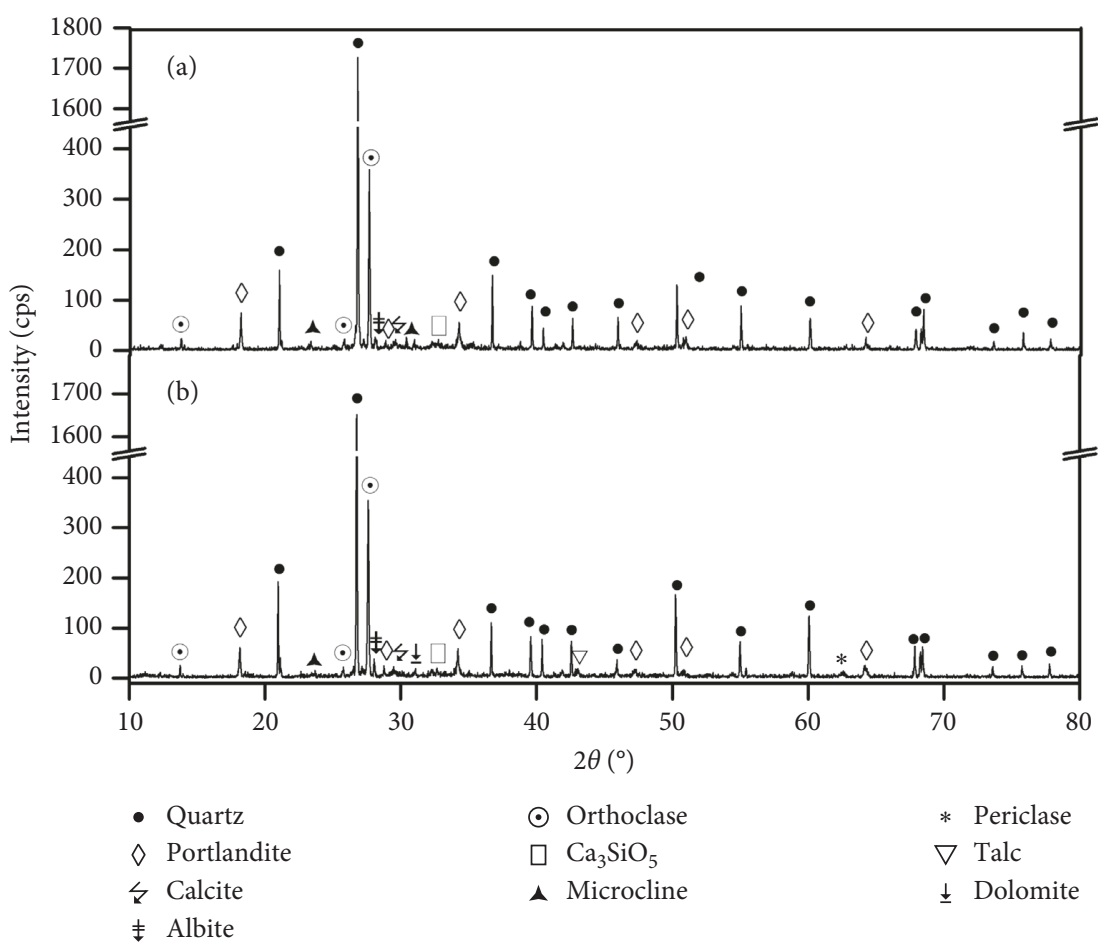

FIgURE 6: XRD analysis of the (a) control mortar (CM) and (b) mortar with 20\% MgO A (MA20).

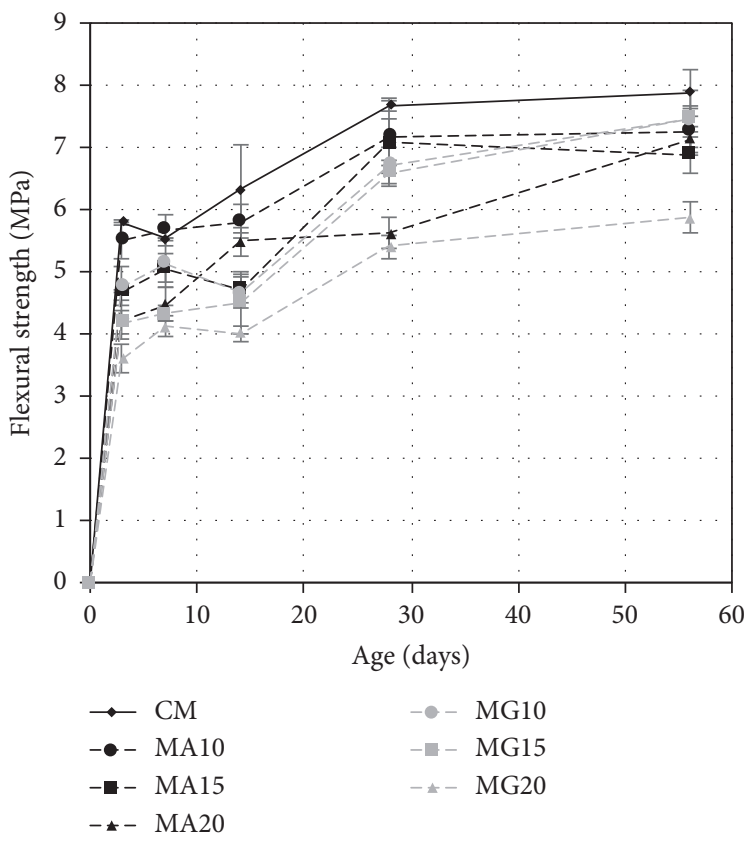

(a)

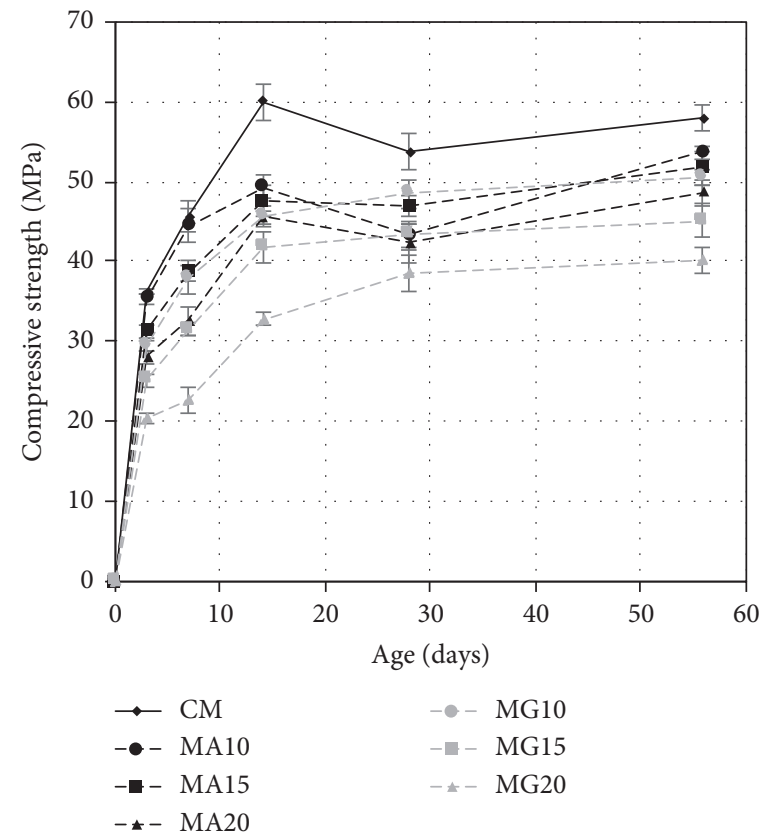

(b)

Figure 7: Flexural (a) and compressive (b) strength of mortars (CM: control mortar; MA: mortars with MgO A; MG: mortars with MgO G).

this higher porosity may exist only at an initial stage as ensuing carbonation yields the formation of further products of hydration reducing the volume of the porous microstructure [62].

Another factor must also be taken into account, which is the suitability of the phenolphthalein test to ascertain the amount of $\mathrm{CO}_{2}$ uptake in the specific case of mortars containing $\mathrm{MgO}$. Since cement was partially replaced with $\mathrm{MgO}$, there was a lower quantity of the former available to produce $\mathrm{Ca}(\mathrm{OH})_{2}$, which exhibits a higher $\mathrm{pH}$ level than that of its counterpart from the hydration of $\mathrm{MgO}$ (i.e., $\left.\mathrm{Mg}(\mathrm{OH})_{2}\right) \quad(\sim 12.5$ and $\sim 10.5$, respectively $)$ thereby 
TABLE 4: Carbonation depth and sorptivity of specimens with increasing $\mathrm{MgO}$ content.

\begin{tabular}{|c|c|c|c|c|c|c|c|c|c|c|c|c|}
\hline \multirow{3}{*}{ Mix } & \multicolumn{4}{|c|}{ Carbonation depth (mm) } & \multicolumn{8}{|c|}{ Sorptivity $\left(\times 10^{-3} \mathrm{~g} / \mathrm{mm}^{2}\right)$} \\
\hline & \multicolumn{2}{|c|}{28 days } & \multicolumn{2}{|c|}{91 days } & \multicolumn{2}{|c|}{3 hours } & \multicolumn{2}{|c|}{6 hours } & \multicolumn{2}{|c|}{24 hours } & \multicolumn{2}{|c|}{72 hours } \\
\hline & Avg. & Std. & Avg. & Std. & Avg. & Std. & Avg. & Std. & Avg. & Std. & Avg. & Std. \\
\hline $\mathrm{CM}$ & 1.32 & 1.44 & 1.76 & 1.47 & 4.21 & 0.09 & 5.49 & 0.17 & 9.69 & 0.61 & 12.12 & 0.50 \\
\hline MA10 & 1.22 & 1.31 & 3.00 & 1.53 & 3.52 & 0.18 & 4.70 & 0.18 & 9.19 & 0.29 & 13.89 & 0.35 \\
\hline MA15 & 1.39 & 1.21 & 4.38 & 0.88 & 3.86 & 0.29 & 5.19 & 0.34 & 10.21 & 0.09 & 15.18 & 0.16 \\
\hline MA20 & 2.39 & 1.93 & 5.83 & 1.20 & 4.35 & 0.08 & 5.68 & 0.12 & 9.93 & 0.25 & 14.31 & 0.52 \\
\hline MG10 & 1.21 & 1.14 & 2.04 & 1.07 & 3.33 & 0.14 & 4.46 & 0.17 & 8.36 & 0.12 & 12.42 & 0.20 \\
\hline MG15 & 1.56 & 1.52 & 4.13 & 1.38 & 3.66 & 0.05 & 4.90 & 0.05 & 8.55 & 0.06 & 12.65 & 0.22 \\
\hline MG20 & 2.74 & 1.82 & - & - & 4.74 & 0.09 & 6.36 & 0.13 & 11.27 & 0.26 & 16.77 & 0.36 \\
\hline
\end{tabular}

Note: CM: control mortar; MA: mortars with MgO A; MG: mortars with MgO G.

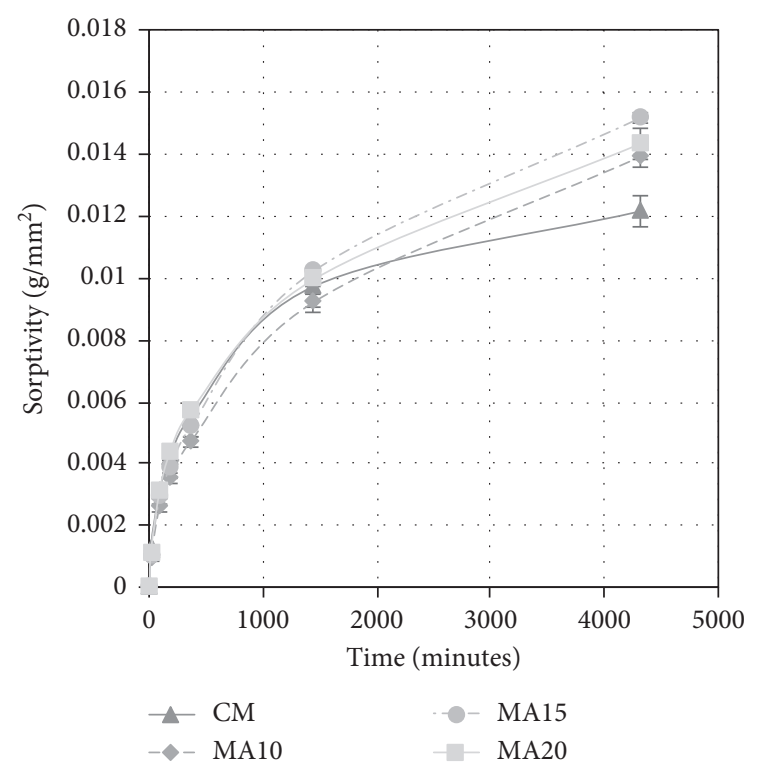

(a)

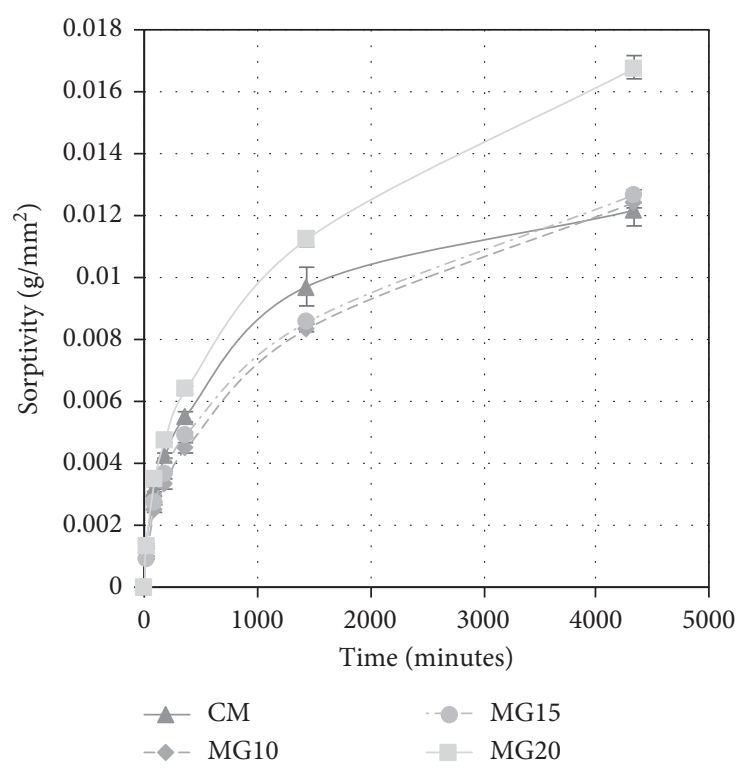

(b)

Figure 8: Water absorption by capillary action of mortars with (a) MgO A (MA) and (b) MgO G (MG).

reducing the specimens' overall $\mathrm{pH}$ level. Nevertheless, the slightly greater mass loss of MA20 specimens in comparison with that of $\mathrm{CM}$ specimens between $500^{\circ} \mathrm{C}$ and $850^{\circ} \mathrm{C}$ in Figure 4 (3.71\% vs. $3.34 \%$, respectively) suggests increased $\mathrm{CO}_{2}$ uptake and thus increased rate of carbonation.

3.4. Water Absorption by Capillary Action. Figure 8 and Table 4 present the results of the water absorption by capillary action of MA and MG. As expected, there was a slight increase in water absorption with increasing $\mathrm{MgO}$ content, though not as obvious for MG10 and MG15. Even though the hydration of $\mathrm{MgO}$ may result in the formation of a phase that exhibits higher volume than that of the initial constituents, replacing a part of the cement will directly decrease the amount of C-S-H that is capable of producing a more tortuous and less interconnected porous network [37], especially after carbonation of the specimen [62, 64]. However, lower total pore volume and water absorption would likely be observed over time with ensuing carbonation reactions and formation of additional magnesium carbonate hydrates $[30,37,65]$.

3.5. Shrinkage. Figure 9 presents the shrinkage strains of MA and MG. Up to a replacement level of $15 \%$, both MA and MG exhibited lower shrinkage strain when compared to the control. This trend was also observed for MA-20, but not for MG-20, which presented significantly higher shrinkage strain. These findings are in agreement with those of others $[19,66]$ and can be explained by the aforementioned reason that $\mathrm{Mg}(\mathrm{OH})_{2}$ presents a greater volume than that of its initial reagents. The specimens' expansion, prompted by the $\mathrm{MgO}$ particles' rapid reaction (typical of light-burned $\mathrm{MgO}$ [67]), occurred 2-3 days after casting. A similar behaviour was observed by Polat et al. [68] for mixes containing up to 7.5\% MgO. After that, a distinctive behaviour of drying shrinkage could be observed, nonetheless significantly offset by the initial expansion; MA-15 and MA-20 exhibited about $80 \%$ lower shrinkage strain after 90 days. Others observed 


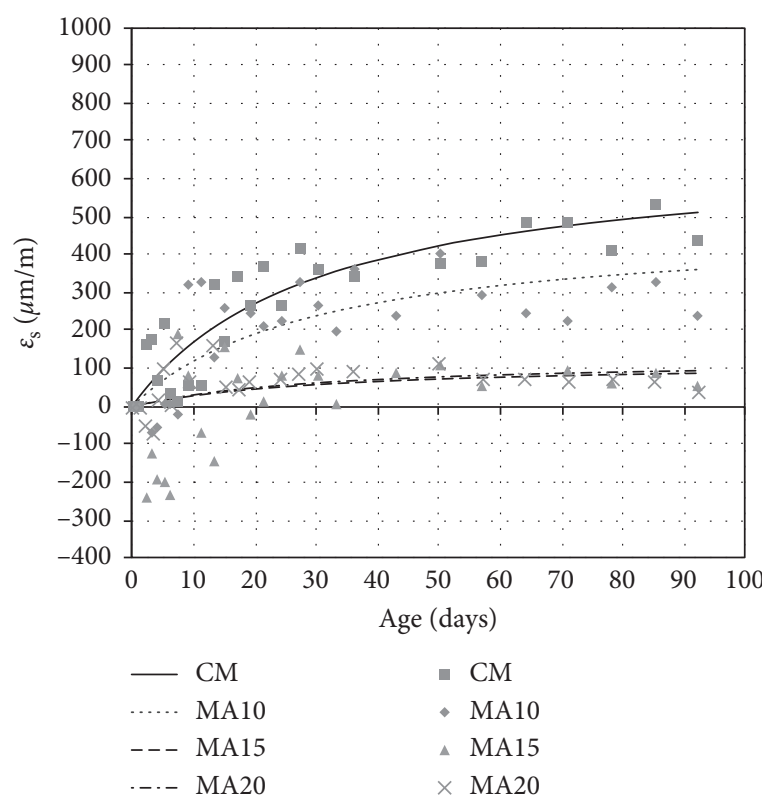

(a)

FIGURE 9: Shrinkage of mortars with

similar decreases in shrinkage for $\mathrm{MgO}$ contents of 7.5\% $[68,69]$. However, for $\mathrm{MgO} \mathrm{G}$, the lower shrinkage strain could be observed only for replacement levels of $10 \%$ and $15 \%$, with values of about $40 \%$ and $20 \%$, respectively, lower than those of the control. This can be explained by the partial hydration of $\mathrm{MgO}$ G before its inclusion and thus did not contribute as effectively in the specimens' expansion as in $\mathrm{MgO}$ A-bearing mortars. Furthermore, for higher replacement levels of $\mathrm{MgO} \mathrm{G}$, the water requirement also increased, which increased the specimens' open porosity and decreased their stiffness. This facilitated the evaporation of free water and decreased the material's ability to restrain shrinkage, which outweighed the expansion of $\mathrm{MgO}$ G.

\section{Conclusions}

An experimental investigation on the role of $\mathrm{MgO}$, as partial cement replacement, in the hydration reactions was performed. The following conclusions were drawn:

(i) Commercially available reactive $\mathrm{MgO}$ exhibits a particle-size distribution that is comparable to that of cement, which avoids further size-reduction processing stages after the manufacture of light burned $\mathrm{MgO}$ before its inclusion in cementitious composites.

(ii) Although the formation of $\mathrm{Mg}(\mathrm{OH})_{2}$ was apparent in $\mathrm{MgO}$-bearing mortars, TGA results did not present visible $\mathrm{M}-\mathrm{S}-\mathrm{H}$-like patterns or those of hydrotalcite-like compounds, suggesting marginal interaction with the cement's products of hydration and siliceous aggregates. Nevertheless, additional analysis should be carried out on specimens without the incorporation of sand to further understand the hydration reactions.

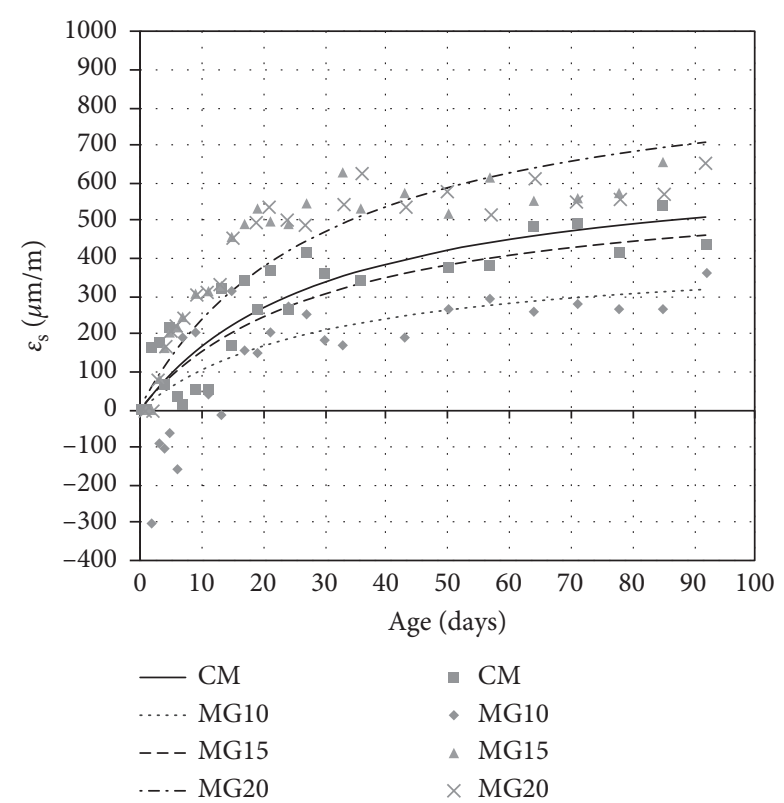

(b)

(a) $\mathrm{MgO} \mathrm{A}(\mathrm{MA})$ and (b) $\mathrm{MgO} \mathrm{G}(\mathrm{MG})$.

(iii) The dilution of cement with progressively higher replacement levels of $\mathrm{MgO}$, and thus lower quantity of C-S-H, probably led to the formation of a less resistant microstructure (lower flexural and compressive strength). Additionally, greater water requirement was observed in mixes including $\mathrm{MgO}$ since the mortars in this study were produced with equivalent consistence and without the use of waterreducing admixtures. The resulting increased porosity, apart from causing a decline in mechanical performance, also led to increased carbonation and water absorption by capillary action.

(iv) Mortars incorporating $\mathrm{MgO}$ are likely to present lower shrinkage strain in comparison with corresponding control specimens made solely with cement. Nevertheless, this enhanced performance ( $\sim 80 \%$ less shrinkage strain for mixes containing $15 \%$ and $20 \% \mathrm{MgO} \mathrm{A}$ ), prompted by the expansion of $\mathrm{Mg}(\mathrm{OH})_{2}$, heavily depends on the quantity of hydrated compounds and reactivity of $\mathrm{MgO}$. From a structural point of view, the $\mathrm{MgO}$-containing elements are likely to exhibit reduced shrinkageinduced cracking thereby improving the material's overall structural and durability-related performances.

\section{Data Availability}

The data used to support the results of this study are included in the manuscript.

\section{Conflicts of Interest}

The authors declare that they have no conflicts of interest. 


\section{Acknowledgments}

The authors gratefully acknowledge the support of the CERIS-ICIST Research Institute, IST-University of Lisbon, and FCT-Foundation for Science and Technology. This work was partly supported by the Andalusian Regional Government (Research Groups FQM-391) and MECD, Spain (FPU13/04030; http://www.mecd.gob.es/educacion-mecd/). The authors also wish to thank Styromag, Grecian Magnesite S.A., Research Plan of the University of Córdoba (2016), and the staff at the Electron Microscopy and Elemental Analysis Units of the Central Research Support Service (SCAI) of University of Córdoba for their technical assistance and the Fine Chemistry Institute of the University of Córdoba for their support.

\section{References}

[1] E. Benhelal, G. Zahedi, E. Shamsaei, and A. Bahadori, "Global strategies and potentials to curb $\mathrm{CO}_{2}$ emissions in cement industry," Journal of Cleaner Production, vol. 51, pp. 142-161, 2013.

[2] M. Schneider, M. Romer, M. Tschudin, and H. Bolio, "Sustainable cement production-present and future," Cement and Concrete Research, vol. 41, no. 7, pp. 642-650, 2011.

[3] C. A. C. D. Souza, A. T. Machado, L. R. P. D. A. Lima, and R. J. C. Cardoso, "Stabilization of electric-arc furnace dust in concrete," Materials Research, vol. 13, no. 4, pp. 513-519, 2010.

[4] W. Tangchirapat, T. Saeting, C. Jaturapitakkul, K. Kiattikomol, and A. Siripanichgorn, "Use of waste ash from palm oil industry in concrete," Waste Management, vol. 27, no. 1, pp. 81-88, 2007.

[5] A. Hasanbeigi, L. Price, and E. Lin, "Emerging energyefficiency and $\mathrm{CO}_{2}$ emission-reduction technologies for cement and concrete production: a technical review," Renewable and Sustainable Energy Reviews, vol. 16, no. 8, pp. 6220-6238, 2012.

[6] R. J. Flatt, N. Roussel, and C. R. Cheeseman, "Concrete: an eco material that needs to be improved," Journal of the European Ceramic Society, vol. 32, no. 11, pp. 2787-2798, 2012.

[7] C. Unluer and A. Al-Tabbaa, "Impact of hydrated magnesium carbonate additives on the carbonation of reactive $\mathrm{MgO}$ cements," Cement and Concrete Research, vol. 54, pp. 87-97, 2013.

[8] EN-197-1, Cement-Part 1: Composition, Specifications and Conformity Criteria for Common Cements, Comité Européen de Normalisation (CEN), Brussels, Belgium, 2011.

[9] P. Mehta, History and Status of Performance Tests for Evaluation of Soundness of Cements. Cement Standards-Evolution and Trends, Symposia Papers \& STPs, STP663: ASTM International, West Conshohocken, PA, USA, 1978.

[10] L. Mo, M. Deng, and M. Tang, "Effects of calcination condition on expansion property of $\mathrm{MgO}$-type expansive agent used in cement-based materials," Cement and Concrete Research, vol. 40, no. 3, pp. 437-446, 2010.

[11] F. Jin and A. Al-Tabbaa, "Strength and hydration products of reactive MgO-silica pastes," Cement and Concrete Composites, vol. 52, pp. 27-33, 2014.

[12] C. Du, "A review of magnesium oxide in concrete," Concrete International, vol. 27, pp. 45-50, 2005.

[13] S. Ruan and C. Unluer, "Comparative life cycle assessment of reactive $\mathrm{MgO}$ and Portland cement production," Journal of Cleaner Production, vol. 137, pp. 258-273, 2016.
[14] M. Liska and A. Al-Tabbaa, "Ultra-green construction: reactive magnesia masonry products," Proceedings of the Institution of Civil Engineers-Waste and Resource Management, vol. 162, no. 4, pp. 185-196, 2009.

[15] C. Unluer and A. Al-Tabbaa, "Enhancing the carbonation of $\mathrm{MgO}$ cement porous blocks through improved curing conditions," Cement and Concrete Research, vol. 59, pp. 55-65, 2014.

[16] T. Zhang, C. R. Cheeseman, and L. J. Vandeperre, "Development of low $\mathrm{pH}$ cement systems forming magnesium silicate hydrate (M-S-H)," Cement and Concrete Research, vol. 41, no. 4, pp. 439-442, 2011.

[17] J. Liu, S. Zhang, Q. Tian, F. Guo, and Y. Wang, "Deformation behavior of high performance concrete containing $\mathrm{MgO}$ composite expansive agent," Journal of Southeast University (Natural Science Edition), vol. 40, pp. 150-154, 2010.

[18] G. Pei-wei, L. Xiao-lin, L. Hui, L. Xiaoyan, and H. Jie, "Effects of fly ash on the properties of environmentally friendly dam concrete," Fuel, vol. 86, no. 7-8, pp. 1208-1211, 2007.

[19] L. Mo, M. Deng, and A. Wang, "Effects of MgO-based expansive additive on compensating the shrinkage of cement paste under non-wet curing conditions," Cement and Concrete Composites, vol. 34, no. 3, pp. 377-383, 2012.

[20] P. Gao, X. Lu, F. Geng et al., "Production of MgO-type expansive agent in dam concrete by use of industrial by-products," Building and Environment, vol. 43, no. 4, pp. 453-457, 2008.

[21] X. Lu, F. Geng, H. Zhang, and X. Chen, "Influence of MgOtype expansive agent hydration behaviors on expansive properties of concrete," Journal Wuhan University of Technology, Materials Science Edition, vol. 26, no. 2, pp. 344-346, 2011.

[22] Y. B. Li, M. Deng, L. W. Mo, and M. S. Tang, "Mechanical properties of concrete with light burnt MgO-based expansive additive under different restrained conditions," Journal of Central South University (Science and Technology), vol. 43, pp. 2534-2541, 2012.

[23] D. R. M. Brew and F. P. Glasser, "Synthesis and characterisation of magnesium silicate hydrate gels," Cement and Concrete Research, vol. 35, no. 1, pp. 85-98, 2005.

[24] T. Zhang, L. J. Vandeperre, and C. R. Cheeseman, "Formation of magnesium silicate hydrate (M-S-H) cement pastes using sodium hexametaphosphate," Cement and Concrete Research, vol. 65 , pp. 8-14, 2014.

[25] S. W. Choi, B. S. Jang, J. H. Kim, and K. M. Lee, "Durability characteristics of fly ash concrete containing lightly-burnt MgO," Construction and Building Materials, vol. 58, pp. 7784, 2014.

[26] F. Jin and A. Al-Tabbaa, "Evaluation of novel reactive $\mathrm{MgO}$ activated slag binder for the immobilisation of lead and zinc," Chemosphere, vol. 117, pp. 285-294, 2014.

[27] D. Nied, K. Enemark-Rasmussen, E. L'Hopital, J. Skibsted, and B. Lothenbach, "Properties of magnesium silicate hydrates (M-S-H)," Cement and Concrete Research, vol. 79, pp. 323-332, 2016.

[28] C. Sonat, W. W. Teo, and C. Unluer, "Performance and microstructure of $\mathrm{MgO}-\mathrm{SiO}_{2}$ concrete under different environments," Construction and Building Materials, vol. 184, pp. 549-564, 2018.

[29] L. J. Vandeperre and A. Al-Tabbaa, "Accelerated carbonation of reactive $\mathrm{MgO}$ cements," Advances in Cement Research, vol. 19, no. 2, pp. 67-79, 2007.

[30] N. T. Dung and C. Unluer, "Carbonated MgO concrete with improved performance: the influence of temperature and 
hydration agent on hydration, carbonation and strength gain," Cement and Concrete Composites, vol. 82, pp. 152-164, 2017.

[31] B. Lothenbach, D. Nied, E. L'Hopital, G. Achiedo, and A. Dauzeres, "Magnesium and calcium silicate hydrates," Cement and Concrete Research, vol. 77, pp. 60-68, 2015.

[32] W. S. Chiang, G. Ferraro, E. Fratini et al., "Multiscale structure of calcium- and magnesium-silicate-hydrate gels," Journal of Materials Chemistry A, vol. 2, no. 32, pp. 12991-12998, 2014.

[33] L. Fernandez, C. Alonso, C. Andrade, and A. Hidalgo, "The interaction of magnesium in hydration of $\mathrm{C}(3) \mathrm{S}$ and $\mathrm{CSH}$ formation using (29)Si MAS-NMR," Journal of Materials Science, vol. 43, no. 17, pp. 5772-5783, 2008.

[34] L. Fernandez, C. Alonso, A. Hidalgo, and C. Andrade, "The role of magnesium during the hydration of C3S and $\mathrm{CSH}$ formation. Scanning electron microscopy and mid-infrared studies," Advances in Cement Research, vol. 17, no. 1, pp. 9-21, 2005.

[35] L. J. Vandeperre, M. Liska, and A. Al-Tabbaa, "Microstructures of reactive magnesia cement blends," Cement and Concrete Composites, vol. 30, no. 8, pp. 706-714, 2008.

[36] C. Roosz, S. Grangeon, P. Blanc et al., "Crystal structure of magnesium silicate hydrates (M-S-H): the relation with 2:1 Mg-Si phyllosilicates," Cement and Concrete Research, vol. 73, pp. 228-237, 2015.

[37] L. Mo and D. K. Panesar, "Effects of accelerated carbonation on the microstructure of Portland cement pastes containing reactive MgO," Cement and Concrete Research, vol. 42, no. 6, pp. 769-777, 2012.

[38] X. Chen, H. Yang, Y. Shi, K. Xiao, and Y. Lin, "Interfacial transition zone characteristics of light-burnt MgO concrete," in Proceedings of 1st International Conference on Civil Engineering, Architecture and Building Materials, CEABM 2011, pp. 397-400, Haikou, China, June 2011.

[39] X. Chen, H. Yang, Y. Zuo, Y. Shi, and K. Xiao, "Interfacial transition zone micro-structure of light-burnt $\mathrm{MgO}$ concrete," in Proceedings of 2nd International Conference on Advances in Materials and Manufacturing Processes, ICAMMP 2011, pp. 514-518, Guilin, China, 2012.

[40] H. Yang, X. Chen, and Y. Zuo, "Interfacial transition zone meso-structure of $\mathrm{MgO}$ concrete loaded to failure by computed tomography," in Proceedings of 2nd International Conference on Civil Engineering and Transportation, ICCET 2012, pp. 403-407, Guilin, China, 2013.

[41] X. Chen, W. Zhao, and P. Li, "Elements enrichment characteristics in interfacial transition zone of MgO concrete," Wuhan University Journal of Natural Sciences, vol. 18, no. 1, pp. 88-92, 2013.

[42] S. Tsivilis, S. Tsimas, A. Benetatou, and E. Haniotakis, "Study on the contribution of the fineness on cement strength," Zement Kalk Gips, vol. 43, pp. 26-29, 1990.

[43] J. M. Pommersheim, "Effect of particle size distribution on hydration kinetics," MRS Proceedings, vol. 85, p. 301, 2011.

[44] D. P. Bentz and C. J. Haecker, "An argument for using coarse cements in high-performance concretes," Cement and Concrete Research, vol. 29, no. 4, pp. 615-618, 1999.

[45] EN-1015-1, Methods of Test for Mortar for Masonry-Part 1: Determination of Particle Size Distribution (by Sieve Analysis), Comité Européen de Normalisation (CEN), Brussels, Belgium, 1999.

[46] EN-1097-3, Tests for Mechanical and Physical Properties of Aggregates-Part 3: Determination of Loose Bulk Density and Voids, Comité Européen de Normalisation (CEN), Brussels, Belgium, 1998.
[47] EN-1097-5, Tests for Mechanical and Physical Properties of Aggregates-Part 5: Determination of the Water Content by Drying in a Ventilated Oven, Comité Européen de Normalisation (CEN), Brussels, Belgium, 2008.

[48] EN-13139, Aggregates for Mortar, Comité Européen de Normalisation (CEN), Brussels, Belgium, 2002.

[49] M. Nepomuceno, L. Oliveira, and S. M. R. Lopes, "Methodology for mix design of the mortar phase of self-compacting concrete using different mineral additions in binary blends of powders," Construction and Building Materials, vol. 26, no. 4, pp. 317-326, 2012.

[50] EN-1015-2, Methods of Test for Mortar for Masonry-Part 2: Bulk Sampling of Mortars and Preparation of Test Mortars, Comité Européen de Normalisation (CEN), Brussels, Belgium, 1999.

[51] EN-1015-3, Methods of Test for Mortar for Masonry-Part 3: Determination of Consistence of Fresh Mortar (By Flow Table), Comité Européen de Normalisation (CEN), Brussels, Belgium, 1999.

[52] EN-1015-6, Methods of Test for Mortar for Masonry-Part 6: Determination of Bulk Density of Fresh Mortar, Comité Européen de Normalisation (CEN), Brussels, Belgium, 1999.

[53] EN-1015-11, Methods of Test for Mortar for Masonry-Part 11: Determination of Flexural and Compressive Strength of Hardened Mortar, Comité Européen de Normalisation (CEN), Brussels, Belgium, 1999.

[54] LNEC-E391, Concrete: Determination of Carbonation Resistance (in Portuguese), National Laboratory in Civil Engineering (LNEC-Laboratório Nacional de Engenharia Civil), Lisbon, Portugal, 1993.

[55] EN-1015-18, Methods of Test for Mortar for Masonry-Part 18: Determination of Water Absorption Coefficient Due to Capillary Action of Hardened Mortar, Comité Européen de Normalisation (CEN), Brussels, Belgium, 2002.

[56] EN-1015-13, Methods of Test for Mortar for Masonry-Part 13: Determination of Dimensional Stability of Hardened Mortars, Comité Européen de Normalisation (CEN), Brussels, Belgium, 1993.

[57] F. Z. Cao, M. Miao, and P. Y. Yan, "Hydration characteristics and expansive mechanism of $\mathrm{MgO}$ expansive agents," Construction and Building Materials, vol. 183, pp. 234-242, 2018.

[58] L. Mo, M. Liu, A. Al-Tabbaa, and M. Deng, "Deformation and mechanical properties of the expansive cements produced by inter-grinding cement clinker and $\mathrm{MgOs}$ with various reactivities," Construction and Building Materials, vol. 80, pp. 1-8, 2015.

[59] L. W. Mo, F. Zhang, D. K. Panesar, and M. Deng, "Development of low-carbon cementitious materials via carbonating Portland cement-fly ash-magnesia blends under various curing scenarios: a comparative study," Journal of Cleaner Production, vol. 163, pp. 252-261, 2017.

[60] G. Ye and T. Troczynski, "Hydration of hydratable alumina in the presence of various forms of MgO," Ceramics International, vol. 32, no. 3, pp. 257-262, 2006.

[61] M. B. Haha, B. Lothenbach, G. Le Saout, and F. Winnefeld, "Influence of slag chemistry on the hydration of alkaliactivated blast-furnace slag-part I: effect of MgO," Cement and Concrete Research, vol. 41, no. 9, pp. 955-963, 2011.

[62] R. X. Zhang and D. K. Panesar, "Water absorption of carbonated reactive $\mathrm{MgO}$ concrete and its correlation with the pore structure," Journal of $\mathrm{CO}_{2}$ Utilization, vol. 24, pp. 350360,2018

[63] H. A. Abdel-Gawwad, S. A. A. El-Enein, M. Heikal, S. Abd ElAleem, A. A. Amer, and I. M. El-Kattan, "Synergistic effects of 
curing conditions and magnesium oxide addition on the physico-mechanical properties and firing resistivity of Portland cement mortar," Construction and Building Materials, vol. 176, pp. 676-689, 2018.

[64] R. Zhang and D. K. Panesar, "Mechanical properties and rapid chloride permeability of carbonated concrete containing reactive MgO," Construction and Building Materials, vol. 172, pp. 77-85, 2018.

[65] N. T. Dung and C. Unluer, "Development of MgO concrete with enhanced hydration and carbonation mechanisms," Cement and Concrete Research, vol. 103, pp. 160-169, 2018.

[66] P. W. Gao, S. Y. Xu, X. Chen, J. Li, and X. L. Lu, "Research on autogenous volume deformation of concrete with $\mathrm{MgO}$," Construction and Building Materials, vol. 40, pp. 998-1001, 2013.

[67] F. Jin, K. Gu, A. Abdollahzadeh, and A. Al-Tabbaa, "Effects of different reactive $\mathrm{MgOs}$ on the hydration of $\mathrm{MgO}$-activated GGBS paste," Journal of Materials in Civil Engineering, vol. 27, no. 7, article B4014001, 2015.

[68] R. Polat, R. Demirboğa, and F. Karagöl, "The effect of nano$\mathrm{MgO}$ on the setting time, autogenous shrinkage, microstructure and mechanical properties of high performance cement paste and mortar," Construction and Building $\mathrm{Ma}$ terials, vol. 156, pp. 208-218, 2017.

[69] R. Polat, R. Demirbola, and W. H. Khushefati, "Effects of nano and micro size of $\mathrm{CaO}$ and $\mathrm{MgO}$, nano-clay and expanded perlite aggregate on the autogenous shrinkage of mortar," Construction and Building Materials, vol. 81, pp. 268-275, 2015. 


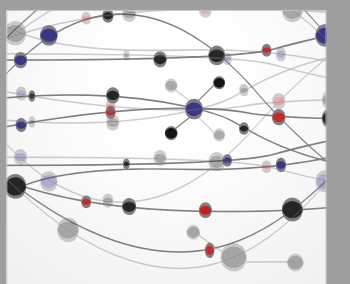

The Scientific World Journal
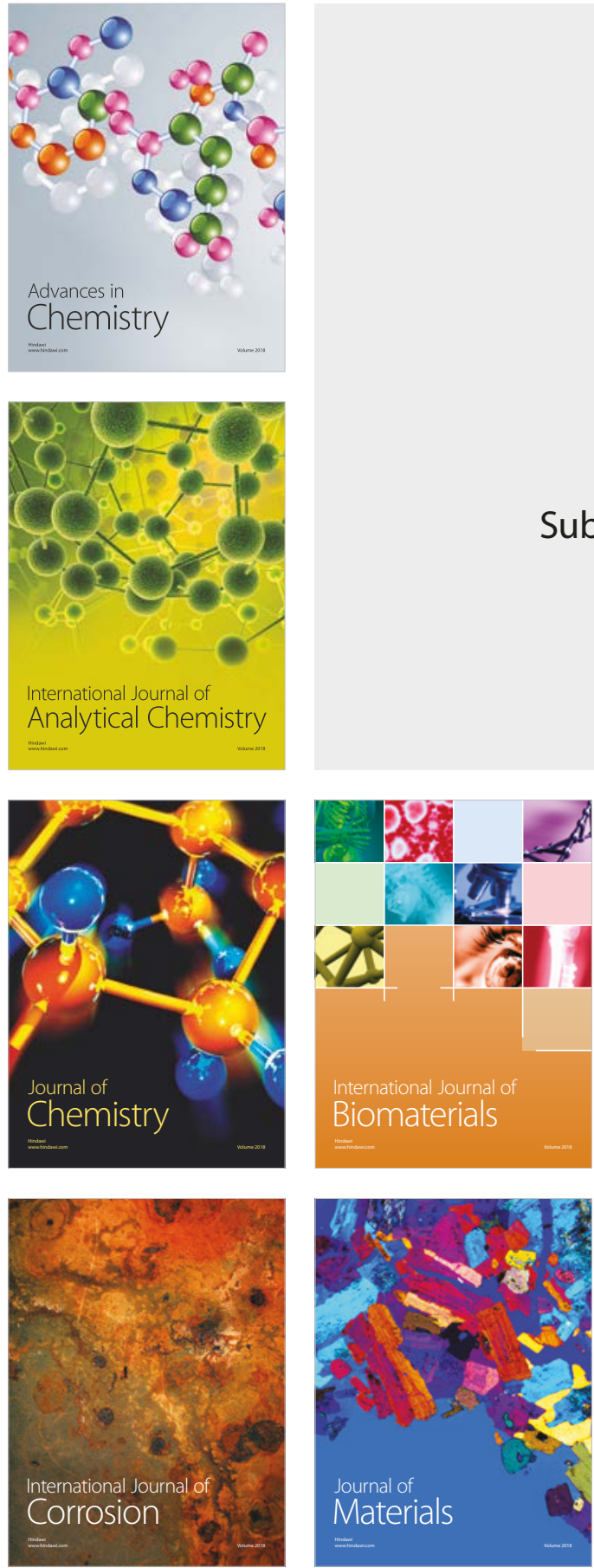

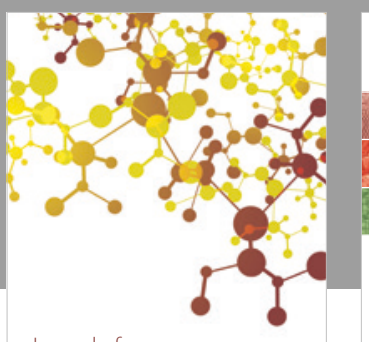

Journal of

Applied Chemistry
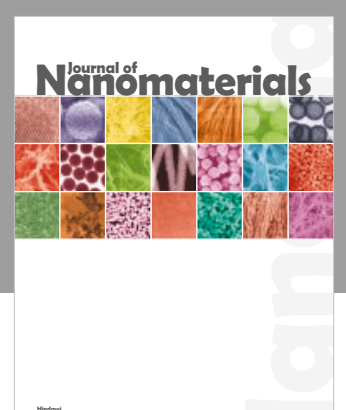

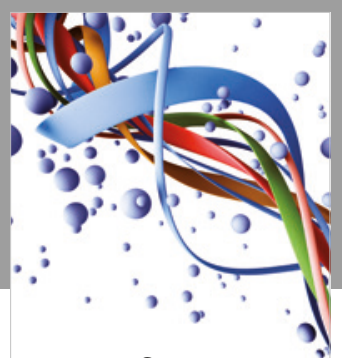

Scientifica

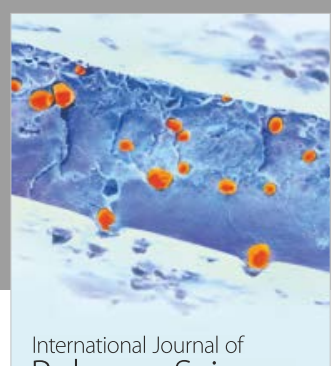

Polymer Science

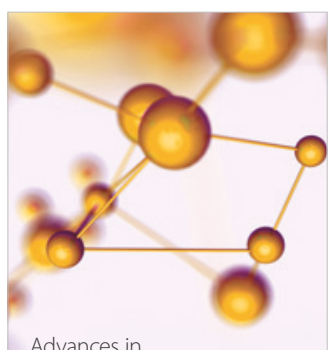

Physical Chemistry
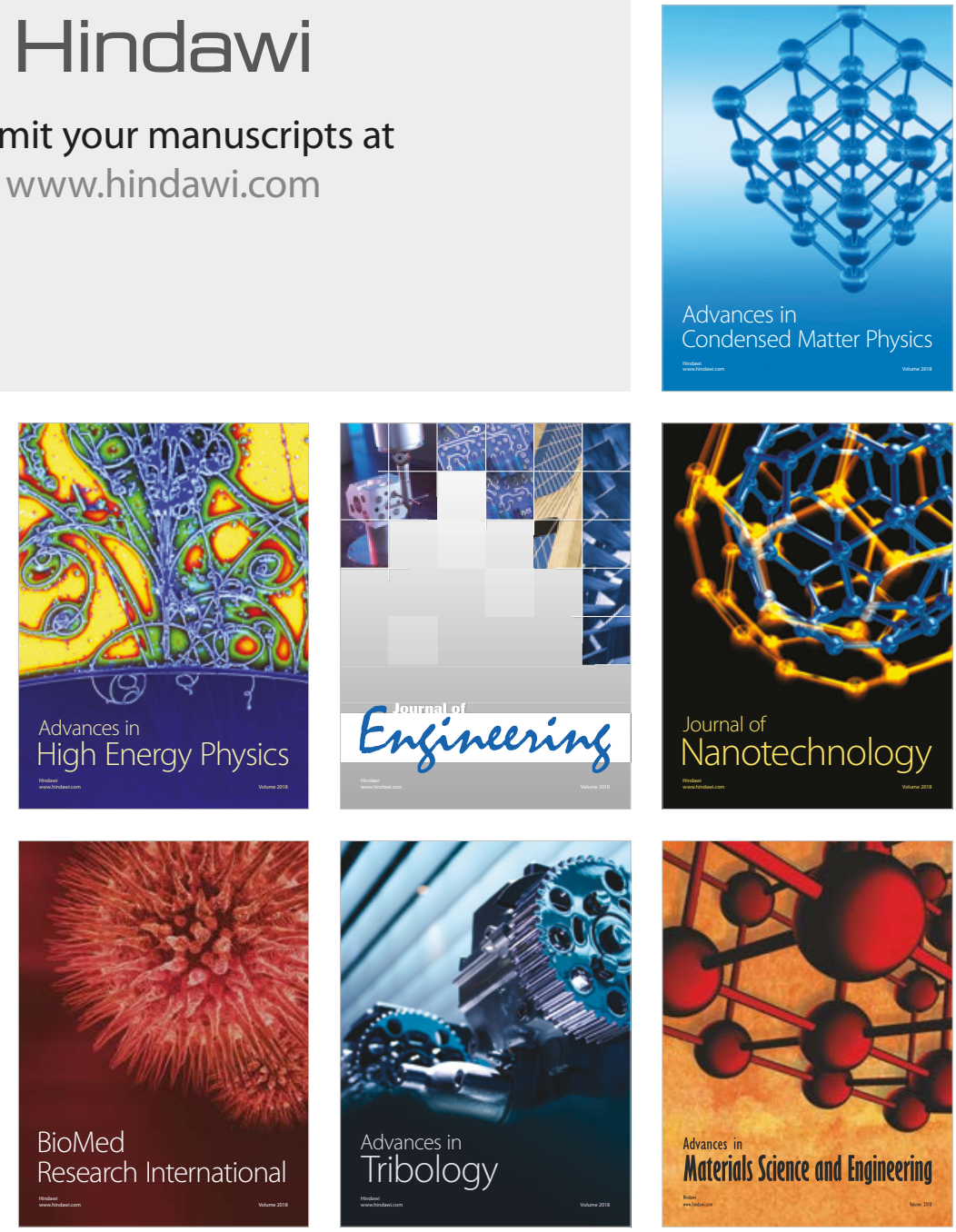